\title{
THE EFFECTIVENESS OF SOMATIC AUDITORY VISUAL AND INTELECTUAL (SAVI) LEARNING APPROACH ASSISTED PROBLEM CARD TOWARDS THE STUDENTS' LIVELINESS AND ACHIEVEMENT ON TRIGONOMETRY MATERIAL OF MATHEMATICS LEARNING
}

\author{
Wulan Maulida, Ponoharjo, Wikan Budi Utami \\ Mathematics Education Department, Faculty of Teacher Training and Education \\ University of Pancasakti Tegal \\ wulanmaulida92@yahoo.com
}

\begin{abstract}
This study aimed to know if the $X$ grade students of SMA Negeri 4 Kota Tegal who were taught by using SAVI learning approach assisted problem card were: (1) reach the learning target achievement, (2) there is a distinction between students and the students who are taught by using SAVI learning approach towards their liveliness and achievement, (3) the liveliness and achievement of students are better than the students who are taught by using SAVI learning approach. The researcher conducted the study at SMA Negeri 4 Kota Tegal in 2016/2017 academic year. The population under study was 282 students. This study used quasi-experimental methodology which consisted of 61 students as the population sample. Cluster random sampling technique was used to determine the population sample. The Instruments of this study were observation on the students' liveliness of mathematics learning which had been passed validity testing by the expert and the achievement test of mathematic learning which had been passed validity and reliability testing. Furthermore, the researcher used proportion test, manova test and $\mathrm{T}^{2}$-Hotteling test as the data analysis technique. The results of the study on the X grade students of SMA Negeri 4 Kota Tegal showed: (1) The students who were taught by using SAVI learning approach assisted problem card reached the target achievement, (2) there were differences between the students who were taught by using SAVI learning approach assisted problem card and the students who were taught by using SAVI learning approach in terms of students' liveliness and achievement. (3) the liveliness and achievement of the students who were taught by using SAVI learning approach assisted problem card were better than the students who were taught by using SAVI learning approach.
\end{abstract}

Keywords: Effectiveness, Somatic, Auditory, Visual and Intellectual (SAVI) Learning Approach, Learning Liveliness, Learning Achievement.

\section{INTRODUCTION}

Nowadays, education is faced a challenge that requires human resources establishment who can meet the global demands. In this case, education is organized as a students' culture and empowerment process which lasts for life (Kartana 2011:20-21). Every student also experience and comprehends the development. Meanwhile, education is defined as an interaction activity. In the interaction activity, the teacher acts as the 
educator for the students. The education is focused on the students' development which leads them to be independent. Hence, the student has to learn in order to develop independently.

In the educational field, a change is a must. For instance, the educational curriculum had been changed from School-based Curriculum (KTSP) to 2013 Curriculum. In order to build high quality education, the government had been established 2013 curriculum to be applied in every school. The application of 2013 curriculum is applied step by step. In the implementation of 2013 curriculum, teachers are required to design effective an meaningful (fun) learning professionally, organize the learning activity, choose the appropriate learning approach, determine the learning procedure and competence establishment actively, and set the criteria of the goal (Mulyasa, 2015:99). There are several components contained in 2013 curriculum. The most prominent thing is the learning approach.

Hence, the teachers have to provide effective learning approach that useful to increase students' interest, motivation and participation. Furthermore, it should be balanced with the teachers' ability in mastering the approach. According to an interview with Ibu Shofuroh, M.Pd as the Mathematics teacher of SMA Negeri 4 Kota Tegal, the school is applying 2013 curriculum. SMA Negeri 4 Kota Tegal use contextual learning approach in the mathematic subject. Contextual learning approach (Contextual Teaching and Learning) is a teaching and learning concept which helps the teachers to link the teaching material with the real world situation. Furthermore, it also encourages the link between students' background knowledge and the application in their daily activities as an individual, a family member and a society. However, in this case, the students are lack of confidence. For instance, the students are afraid to answer the question in front of the class. It makes them become passive learners. This school is considered as one of the excellent schools. However, in fact, there are many students who have problems and barely reach the mathematic learning achievement. This phenomenon was showed by the test result that indicated only $40 \%$ of the students who passed the minimum score which was 70.

Dave Meier develops SAVI as one of learning approaches that feasible for learning approach (Meier, 2002:91). SAVI learning approach integrates the physical movement with intellectual activity, and uses all of the senses which have a big impact on learning 
activities. Physical movement increases the mental process. The part of human brain that involved in the body movement (motor cortex) is placed next to the part of the brain which functioned as thinking and problem solving. Hence, it prevents the body movement that effect on the brain prevention to think optimally. Otherwise, the body activity in learning process helps the students to increase their human intelligence.

A previous study conducted by Harry Dwi Putra (2011) entitled "Pembelajaran Geometri dengan Pendekatan SAVI (Somatis, Auditori, Visual, dan Intelektual) Berbantuan Wingoem untuk Meningkatkan Kemampuan Analogi Peserta Didik " stated that the students who acquired SAVI learning approach assisted Wingeom had better mathematic analysis ability than the students who acquired conventional learning. Another study conducted by Riska Maghfiroh (2016) entitled "Keefektifan Pendekatan Pembelajaran SAVI (Somatis, Auditori, Visual, dan Intelektual) Terhadap Sikap dan Prestasi Belajar Matematika" found that SAVI learning approach was better than conventional learning approach towards the students' affective and mathematics achievement.

In addition, Dian Mariya (2013) conducted a study entitled "Keefektifan Pembelajaran SAVI (Somatis, Auditori, Visual, dan Intelektual) Berbantuan Alat Peraga Terhadap kemampuan Pemecahan Masalah" suggested that SAVI learning approach assisted learning tool helped the students to reach the learning achievement better than the expository model of the triangle circumference and area materials. Form the rationales above, the researcher concludes that SAVI learning approach is better than conventional learning approach.

In order to support SAVI learning approach, it is important to use learning media. existence of teaching media is very important. One of the medias that support SAVI learning approach is problem card. Problem card contains further learning activity and unusual question (non-routine question). This card is given to the students as an individual or group task that has to be completed and presented by the students along with the problem solving explanation. The variations of the questions in the problem card may increase students' interest and participation to find the solution. It helps the students to improve their learning achievement.

In order to get further understanding of the students' liveliness and learning achievement in the trigonometry material of mathematics learning and considering the 
explanation above, the researcher conducted the study entitled "The Effectiveness of Somatic Auditory Visual and Intellectual (SAVI) Learning Approach Assisted Problem Card towards the Students' Liveliness and Achievement on Trigonometry Material of Mathematics Learning".

\section{RESEARCH METHODOLOGY}

In this study, the researcher used cluster random sampling. The population under study was all of the X grade students of SMA Negeri 4 Kota Tegal in 2016/2017 academic year. The total of the population was 282 students from 9 classes. Furthermore the researcher randomly chosen 2 classes out of all $\mathrm{X}$ grade classes as the population sample for the study, which were: X MIA 1 class that consisted of 32 students as the experimental group that taught by using SAVI learning approach assisted problem card and X MIA 2 class with 29 students as the control group that taught by using SAVI learning approach without assisted problem card.

The researcher conducted quantitative approach with quasi-experimental research approach. In this study, there were two classes randomly chosen by the researcher. The first class acquired the treatment $\left(\mathrm{X}_{1}\right)$ while the second class not acquired the treatment $\left(\mathrm{X}_{2}\right)$. The class that aquired the treatment was called as the experimental group whereas the class that not acquired the treatment was called as the control group. The independent variable was SAVI learning approach assisted problem card. On the other hand, the dependent variable was the students' liveliness and mathematics learning achievement.

Documentation, test, and observation were used by the researcher as the data collection methods. Documentation used to obtain the data about name, number of the students of population sample and experimental class, and the final exam score of the first semester of 2016/2017 academic year. The questions of the final exam were in form of description or essay. The observation used to obtain the information about the effectiveness of SAVI learning approach assisted problem card and to know the students liveliness in mathematics learning. The pre-requisite materials of trigonometry learning were: angle and radian measurement, triangles' trigonometric ratio, trigonometric ratio of specific angle and angular trigonometric ratios across all quadrants. 


\section{Findings and Discussions}

Table 1.The comparison between students' liveliness in the experimental class and in the controlled class.

\begin{tabular}{cccc}
\hline No. & Score & Experimental Class & Controlled Class \\
\hline 1 & $\mathrm{~N}$ & 32 & 29 \\
\hline 2 & Mean & 34,28 & 32,41 \\
\hline 3 & Median & 36,00 & 33,00 \\
\hline 4 & $\begin{array}{c}\text { Standard of } \\
\text { Deviation }\end{array}$ & 6,141 & 4,975 \\
& Variance & 37,707 & 24,751 \\
\hline 5 & Maximum & 45 & 42 \\
\hline 6 & Minimum & 20 & 20 \\
\hline 7 & & &
\end{tabular}

Table 4.5 shows the highest score of the each class. The highest score of the experimental class which consisted of 32 students was 45 . On the other hand, the highest score of the controlled class that consisted of 29 students was 43 . The result indicated that the experimental class had 3 points higher than the controlled class. Furthermore, the lowest score in the experimental and controlled class showed the same score that was 20. Based on this description, it could be concluded that the highest students' individual liveliness was in the experimental class. Table 4.5 also shows the average score in each class. The experimental class had 34.28 points, while the controlled class had 32.41 points. It indicated that the students' score in the experimental class was higher than the students' score in the controlled class. Moreover, the experimental class's median score was also higher than the median score in the controlled class with 36.00 points, while the controlled class was 33.00 .

Moreover, Table 4.5 shows the standard deviation and variant score of the classes. It pointed that the experimental class had higher score than the controlled class. The standard deviation score of the experiment class was 6.141 , while in controlled class was 4.975 . The variance score in the experiment class was 37.707 while in the control class was 24,751. These differences indicated that the distribution score of the experimental class was more varied, while the controlled class was assembling above the average score. In conclusion, the experimental class students' liveliness was higher compared to the controlled class students.

Table 2. The Comparison between the Students' Learning Achievement on the Experimental and Controlled Class

\begin{tabular}{lccc}
\hline & Score & Experiment Class & Control Class \\
\hline 1 & $\mathrm{~N}$ & 32 & 29 \\
2 & Mean & 81.76 & 70.34 \\
3 & Median & 83.00 & 75.00 \\
4 & Standard Deviation & 10.162 & 15.877 \\
5 & Variant & 103.261 & 252.091 \\
6 & Maximum & 100 & 98 \\
7 & Minimum & 58 & 40 \\
\hline
\end{tabular}


Table 4.10 shows the highest and the lowest score of each class. Firstly, the highest score of the experimental class which consisted of 32 students was 100. It was higher compared to the 29 students in the controlled class's highest score which was 98 . There was 2 points higher of the experimental class compared to the controlled class. Secondly, the lowest score in the experimental class was 58, while in the controlled class was 40 . There was 18 points higher in the experimental class compared to the controlled class. Based on the rational above, it could be concluded that the highest students' individual learning achievement was in the experiment class and the lowest one was in the control class.

Table 4.10 also shows the average score of the each class. The experimental class had 81.76 and the controlled class had 70.34. It could be concluded that the experimental class students' score was higher than the controlled class. The median score of the experimental class was higher than the controlled class which were 83.00 and 75.00. Table 4.5 shows the standard deviation and variant score from the experimental class that lower than the controlled class. The standard deviation score in the experimental class was 10.162, while in controlled class was 15.877. The variance score in the experimental class was 103.261, while the controlled class was 252.091. These differences indicated the distribution score of the controlled class was more varied, compared to the experimental class that assembled above the average score. In conclusion, the experimental class students' learning achievement was higher than the controlled class students.

The researcher used normality test to know the normality or to show that the sample was from normal distribution population. The result of the normality test showed

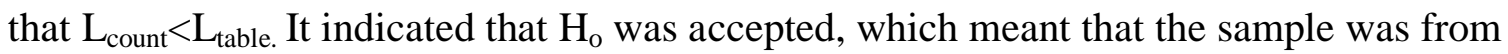
normal distribution population. Homogeneity test conducted to investigate the similarity of the data that would be analyzed by the researcher. Homogeneity test showed that $\mathrm{X}^{2}$ count $\leq \mathrm{X}^{2}$ table for the students' liveliness and the students' achievement in mathematic learning. Therefore, it could be concluded that both data was homogeny.

After the result of the research data showed normal distribution and homogeny, the researcher conducted hypothesis test as the follows: (1) hypothesis test of the students' achievement percentage using proportion test. It conducted to investigate the achievement percentage of the students who were taught by using SAVI learning approach assisted problem card. The calculation of proportion analysis test found that $\mathrm{Z}_{\text {count }}=2,449$. Moreover, the result of $\mathrm{Z}_{\text {count }}$ was consulted with $\mathrm{Z}_{\text {table }}$ with the significance level up to $5 \%$. The result obtained $Z_{\text {table }}=2,042$. Because of the $Z_{\text {count }}>Z_{\text {table }}$ or $2,449>2,042$, it indicated that $\mathrm{H}_{\mathrm{o}}$ was rejected. It meant that the students' who had been 
taught by using SAVI learning approach assisted problem card exceeded $75 \%$ of the mathematics learning achievement. (2) this test conducted to investigate which learning approach better between SAVI learning approach assisted problem card and SAVI learning approach without assisted problem card towards students' liveliness and achievement in mathematic learning. It was tested by using manova test.

The result of the manova test showed that $\lambda_{\text {count }}=0,807$. Furthermore, the result consulted to $\lambda_{\text {tabel }}$ with $\mathrm{p}=$ total amount of response variable $=2, \mathrm{~V}_{\mathrm{H}}=$ degree of treatment freedom $=1$, and $\mathrm{V}_{\mathrm{E}}=$ degree of error freedom $=59$ and significant level $5 \%$. The result of the test obtained value $\lambda_{\text {table }}=0,858$ that caused by $\lambda_{\text {count }}<\lambda_{\text {table. }}$ It indicated that $\mathrm{H}_{0}$ was rejected. The result showed that meant there was a distinction between the student who were taucht by using SAVI learning approach assisted problem card and the students who were taught using SAVI learning approach without assisted problem card in terms of students' liveliness and mathematics learning achievement. (3) Hypothesis test for determining the most effective learning approach used $\tau^{2}-$ Hotelling test. The result of the data obtained $\tau_{\text {hitung }}^{2}=13,322$. Furthermore, the result consulted with $\tau^{2}$ tabel response variable $=2$ and $\mathrm{dk}$ denominator 59 and significant level was $5 \%$, so it obtained $\tau_{\text {tabel }}^{2}=6,413$. Evidently, the result showed that $\tau_{\text {hitung }}^{2}>\tau_{\text {tabel }}^{2}$ or $13,322>6,413$. It indicated that Ho was rejected that meant the students who were taught by using SAVI learning approach assisted problem card better than the students who were taught by using SAVI learning approach without assisted problem card in terms of students' liveliness and mathematics learning achievement.

Somatic, auditory, visual and intellectual (SAVI) learning approach assisted problem card is suitable used by the students to improve their liveliness and learning achievement. Because, somatic, auditory, visual and intellectual (SAVI) learning approach assisted problem card is an active learning approach. In this learning approach, the teachers engage the student into interesting learning that connected to the real world situations. Pleasure learning actually helps the students to improve their understanding of the material. In this case, somatic, auditory, visual and intellectual (SAVI) learning approach assisted problem card is useful to routinely practice students' task exercised learning in the problem card. Therefore each student can finish the question individually or in group. Furthermore, the students may present the result of their works in front of 
the class. This activity helps the students to improve their public speaking skills. Through this approach, the students become more active in leaning activity. Therefore, it is expected that the students can improve their development and material understanding that affect on their learning achievement.

\section{CONCLUSION}

The result of the study on the $\mathrm{X}$ grade students of SMA Negeri 4 Kota Tegal in 2016/2017 academic year with basic trigonometry material would be explained as follows: (1) The X grade students of SMA Negeri 4 Kota Tegal who were taught by using somatic, auditory, visual and intellectual (SAVI) learning approach assisted problem card reached the learning goal achievement (2) there was a distinction between the students who were taught by using Somatic, auditory, visual and intellectual (SAVI) learning approach assisted problem card and the students who were taught by using Somatic, auditory, visual and intellectual (SAVI) learning approach without assisted problem card in terms of students' liveliness and mathematics learning approach. (3) Somatic, auditory, visual and intellectual (SAVI) learning approach assisted problem card was better than Somatic, auditory, visual and intellectual (SAVI) learning approach without assisted problem card.

\section{REFERENCES}

Arikunto, Suharsimi. 2013. Research procedure. Jakarta: Rineka Cipta.

Darmadi, Hamid. 2011. Educational Research Methods. Bandung: Alfabeta.

Dwi, Heri. 2011. Learning Geometry with SAVI Approach (Somatis, Auditori, Visual, and Intellectual) Wingoem Helped to Improve Analogic Ability of Learners. Proceedings of the National Seminar on Mathematics Education STKIP Siliwangi Bandung.Volume 1, ISBN 978-602-19541-0-2

Kartana, Tri Jaka. 2011. Education Management (Implementation In School). Pancasakti University of Tegal.

Maghfiroh, Riska. 2016. The Effectiveness of SAVI Learning Model (Somatis, Auditori, Visual, and Intellectual) to the Attitude and Achievement of Mathematics Learning. Thesis. Pancasakti University of Tegal.

Mariya, Dian. 2013. The Effectiveness of SAVI-Assisted Learning Aids on Problem-Solving Abilities. Journal of Mathematics UNNES. Volume 2. ISSN 2252-6927.

Meier, Dave. 2002. Creative and Effective Guidelines Designing Education and Training Programs. Translated By Rahmani Astuti From The Accelarated Learning Hand Book (2000). Bandung : Kaifa.

Mulyasa. 2015. Development and Implementation of Curriculum 2013. Bandung: Remaja Rosdakarya.

Sudjana, Nana. 2005. Statistics Methods. Bandung: Pt Tarsito. 